\title{
Image of Woman in John La Tier's Film The Tell Tale Heart (2016): An Ecranisation Analysis
}

\author{
Weni Mayendri ${ }^{1}$, Maria Josephine Mantik ${ }^{2}$ \\ \{weni.mayendri@ui.ac.id\} \\ Magister Ilmu Susastra, Faculty of Humanities, Universitas Indonesia
}

\begin{abstract}
The Tell Tale Heart (1843) is one of the famous short story written by Edgar Allan Poe's (1809-1849). This short story was adapted into a film in 2016 with the same title. However, the film add a female figure that change the meaning of that work. The female character, known as Ariel, drive the main character into a psychopathic behavior, including fear, anger, and desire to kill the Old Man. This study is a decriptive qualitatif reseach that conducted by analyzing the female character of the film. The analysis in this research is done based on the image of woman in literature by Mary Anne Ferguson (1977). This reseach found that woman, in this film, is portrayed as the seductress goddes, the sex object, and weak woman.
\end{abstract}

Keywords: Ecranisation, object, seductress goddes, women, The Tell Tale Heart

\section{Introduction}

Edgar Allan Poe (1809-1849) was one of the most influential figures in American and world literature. He is a writer, literary critic and editor. Throughout his career, Poe has produced many short stories, poems, criticisms, and essays. Poe is known for works with satirical humor, horror, mystery, and detective stories, as well as displaying the psychological dark side of humans. Poe's ability to present stories with a creepy and intriguing aura is what makes Poe given the nickname as the Master of Macabre Art and Horror. One of Poe's bestknown works is the short story "The Tell-Tale Heart" [1]. This whole story is about a murder committed by a 'crazy' person. Interestingly, the narrator, who is the main character, in this short story is the perpetrator of the murder. The mystery of the short story "The Tell-Tale Heart" lies in the narrator's very detailed and logical recognition of the murder he committed. However, this short story does not provide other witnesses, even evidence that shows whether the murder actually occurred.The narrator in the short story "The Tell Tale Heart", like the main character in Poe's other works,was portrayed as someone who has a mental disorder. The narrator in this short story had excessive paranoia and anxiety towards something that drives them to commit a crime [2]. The discussion on "The Tell Tale Heart" is entirely focused on the narrator's thoughts, actions and madness. This is due to the lack of context given by the work to see other causes of the thoughts and attitudes of the main characters. The limitations of this context also produce a variety of assumptions related to the psychological condition of the narrator. In other words, the researcher will not understand the actions of the narrator without entering and understanding the narrator's madness. 
This short story is quite phenomenal, so it is adapted into various forms, including theater, film, and animation. The first film adapted from this short story is a silent film called The Insane in 1928, directed by Leon Shamroy. This film remains faithful and does not change the narrative in the short story at all. Meanwhile, the latest adaptation of the short story "The TellTale Heart" is a film with the same title. The film was directed by John La Tier in 2016.

The Tell-Tale Heart Short Story (1843) has been analyzed in several studies, one of which is a study by Shamaila Amir with the title "Analysis of the Short Story" The Tell-tale Heart by Edgar Alan Poe " [3]. The purpose of the analysis of this paper is to reveal the sociopsychological narrator of this short story by using the discourse analysis method. This paper discusses aspects that influence the narrator's criminal acts and the causes of the narrator's expressing the killings he committed himself. The findings of this study conclude that this short story was written to show a form of psychiatric problems namely paranoia and mental deterioration. This short story does not explain the sex of the main character, so many argue that the protagonist is a young man or younger than The Old Man. However, Gita Rajan in her article entitled "A Feminist Rereading of Poe's 'The Tell-Tale Heart"' (1998) argues that the protagonist was a woman who wanted to break away from male domination and decided to kill him [4]. By using Lacan's psychoanalytic theory, this research shows that there is an opposite form of Oedipal myth. According to Rajan, the narrator in this short story wanted to defeat the power possessed by men.

Another analysis is an analysis of psychopathic behavior in the main character of this short story. Daniela S. Fierro in her analysis, entitled "The Psychopath in Destoyevsky and Poe: A Psychological Insight of a Killer" [5], discusses the traits of possessed by psychopaths. In the article, Fierro discusses "The Tell-Tale Heart" and two of Destoyevsky's works entitled "William Wilson" (1839) and The Brother Karamazov (1880). According to Fierro, psychopathic behavior in the main character of the works above can be seen from the attitude of lack of symphaty, very detailed planning, and easy crime. However, Fierro saw the main character in "The Tell-Tale Heart" has a very high obsession to finish off his opponent.

Meanwhile, the the ecranisation of that short story, The Tell Tale Heart, tells the story of a patient who killed his doctor because he felt frightened by the eyes of the doctor. The protagonist in this film made a confession about his murder of Old Man. Based on this confession, the protagonist, named Sean, revealed his assault on killing Old Man was to save himself and his girlfriend named Ariel. However, the murder did not make him feel separated from feelings of being haunted by Old Man. Short story "The Tell Tale Heart" is analyzed by many literary researchers because of its uniqueness and mystery. This short story is also used as an example of a literary work that presents the dark side of the human psyche, whether male or female. However, there has been no research on this short story ecranisation; The Tell Tale Heart and analyze the image of women potrayed in the film. Despite having almost the same narrative, the change of several elements changed the ideology conveyed in this film. A very big difference in this film is the addition of female characters that influence the thoughts and actions taken by the main characters. The female figure is presented as a visualization of fear, ambition and desire to escape from the influence of Old Man on the main character. The addition of these female leaders also had an impact on the changing position of the main character. The ecranisation, is the result of interpretation from a literary works into a film [6]. The process of an ecranisation involve many changes in some aspects of the works. The basic changes that occurred in an ecranisation is the tranformation of the text or the script into a picture. Istadiyantha states that it does not matter if the film being loyal or not to its text [7]. Each work has its own medium and viewers or readers. In other word, the differeces-aspect, characters, interpretations, and images is a must in an ecranisation. 


\section{Research Method}

Ferguson explain that there are many stereotypes of woman in patriarchal society found in literary work [8]. Woman is potrayed as submisive, seductress goddes, sex object, and angel that always show kindness and love. These images become an ideal potray of a good women. The have to be the person that all men want. On the other hand, independent woman with degrees, unmaried, and able to take control; seen as a bad woman. Those women is out of the rules and norms that set by the patriarcy system in the society. The images of woman by Ferguson above will be analyzed in a decriptive qualitative research in order to find how this film portayed a woman.

\section{Result And Discussion}

The short story "The Tell Tale Heart" only has two main characters namely, the narrator and Old Man. In this short story, the narrator commited murder with very organized planning only influenced by his excessive madness and fear of something. Poe's work shows that humans have a wild side that causes humans to be able to commit crimes. Poe's works are seeing the dark side of humans through the madness of the characters who sound the real reality. However, Sean's psychic dark side in this film was actually presented in the figure of a female character named Ariel. Ariel was a source of fear and crazy ideas that have in Sean's mind. In other words, Sean's anxiety and madness described in the short story "The Tell Tale Heart" were presented in the form of Ariel's speech and behavior. The addition of Ariel in this film shows the embodiment of partriarchal cultural stereotypes towards woman in literary works. Woman in this film are imaged in various forms, namely, the figure of the goddess of temptation, women potrayed as a weak person and must be saved by male figures. In this film Ariel was described as a woman who was very intelligent and sensual. Ariel was even able to attract Sean's attention when they first met.

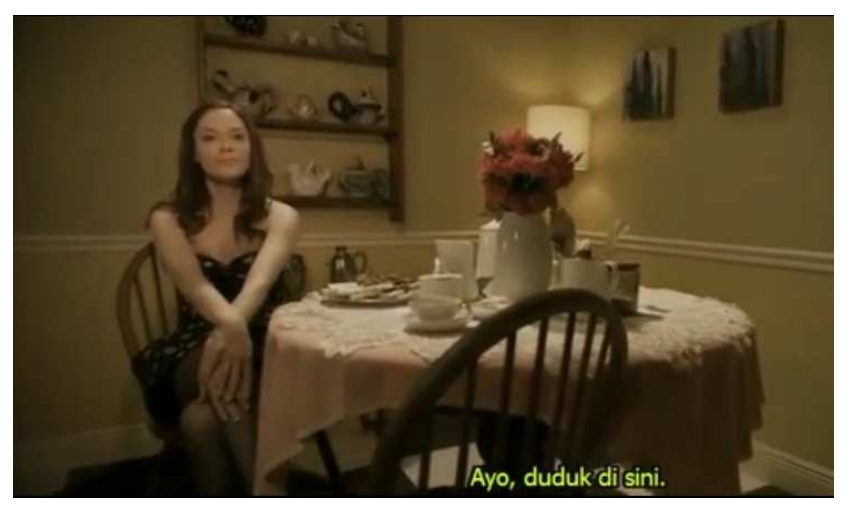

Ariel was portrayed as a figure that explained by Ferguson in the Image of Woman in Literature as The Seductress Goddes. Ferguson mentions that a tempt goddess uses her physical appearance to attract man. This can be seen from the appearance, clothing, attitude, sitting position, and persuasive sentences that were raised by Ariel to attract Sean's attention. It is this attitude and appearance that makes Ariel have very strong control in every action 
Sean will take. This influence made Sean slowly lose control of himself and be under the influence of Ariel's remarks. Ariel gradually build up the anxieties that Sean tried to suppress.

Sean: I don't know what choice gonna matter. This is the quickest way to take me out of here. So, i take this. (taking the medicine)

Ariel: Out? I tried a hundred times to get out. You'll never get out. $(37: 42-37: 48)$

....

Ariel's statement about never getting out contradicts what Old Man said to Sean.

Old Man: You can come and go as you please, Sean. The only one is keeping you here is you (39:55)

In the two quotes above, Sean tried to break away from Old Man by trying to recover and leave Old Man. Sean's actions were also supported by Old Man by giving Sean the freedom to choose to leave him or continue treatment. Sean absolutely had no desire kill the old man. Sean's attitude was different form the short story's short story who chosed to build his fear and hatred of Old Man every day. However, optimism and Sean's efforts were hindered and broken by Ariel. Ariel stressed that the effort to escape from the Old Man was futile. At this stage it appears that the pressure exerted by Ariel is greater than Sean's fear caused by Old Man's eyes.

Ariel also became a woman who tried to awaken imaginations and nightmares to push Sean further. Ariel said "Everyone has a bad dream, Sean. Dream of falling, being cashed, being hurt, teeth falling out. Ariel's explanation of nightmares reminded Sean every nightmare he had. Ariel's deliberate depiction of details deliberately created Sean's fear of those dreams. In addition, Aril is portrayed as a figure that incites Sean to get rid of Old Man. Ariel's attempt to influence Sean is shown in the quote below.

Ariel: "The Old Man is not any smarter than you and I. We don't need him watching us to get better." (46:58 - 47:08)

Sean: "clarity had return. The Old Man no longer had hold on me. The Old Man no longer had hold on us" $(48: 48-49: 00)$

The word 'watching' expressed by Ariel in the quotation above can be a form of Old Man's supervision of Sean. Old Man for Sean, both in short stories or films, like someone who always oversees his behavior. This monitoring produced fear and forced Sean to act according to the rules set by Old Man. In the story it is explained that the narrator considers that Old Man's eyes are like vulture watching and ready to stare at his food. However, at this point Old Man's eyes became Sean's supervisor to continue to undergo medical therapy and cure Sean. The different purpose of this surveillance makes Sean in the film a figure who remains obedient to Old Man.

However, Ariel's attitude towards the surveillance changed Sean's perspective on Old Man. Ariel shows that supervision does not provide any benefit for themselves other than fear. This sentence becomes a justification for the fear and hate that is hidden by Sean. Ariel's statement was also a declaration for Sean to break free from Old Man's gaze. The phrase 'no longer hold on us' becomes a benchmark for Sean to escape the emotional bonds that hold anger and hatred towar Old Man. This representation of women also found on Shakespeare's work. Lady Macbeth is portrayed as ambitious and driven woman, she can convince her husband to kill the king [9]. 
Furthermore, Ariel was also portrayed as a passive woman who is waiting to be saved by men. The image of a passive woman are often displayed in literary works [10]. Peterson added that women are always imaged as someone who feels threatened and controlled by men. However, women just stay quiet and wait for a person - most likely also a man (imaged as a father, husband, brother and boyfriend) - will save themselves.

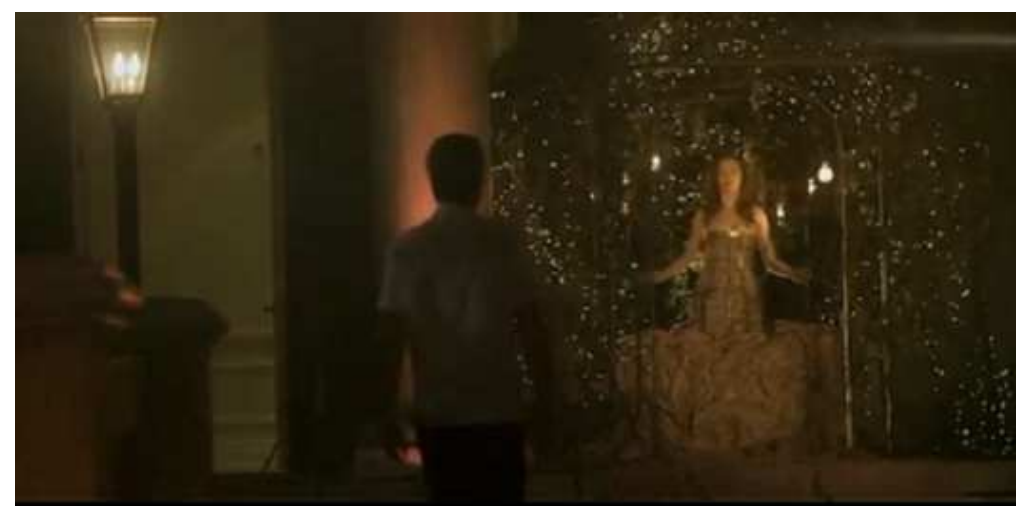

Ariel who was taken hostage was also described as luxurious and elegant like a princess waiting for a prince to save her. Meanwhile, Sean is shown as a simple figure but is able to release Ariel from the hostage. These two contrasting things show Ariel's helplessness and Sean's greatness to give her freedom. The visualization above illustrates two binary oppositions between men and women with the standard of judgment according to male norms.

This binary opposition, according to Ferguson, portrayed men as being active and able to succeed in various fields. Meanwhile, women are seen as passive and accept every treatment that befalls them. On one hand, Ariel was portrayed as someone who is intelligent and able to influence Sean's way of thinking, but on the other hand she was unable to use her intelligence to escape. In fact, from the picture above Ariel looks accepting and does not feel pressured at all even though she was in chain.

Ariel, who was weak and unable to save herself, became a platform for Sean to both free himself from Old Man's supervision.

Ariel: I want to be free. I want to get out of this house.

Sean: I kill the Old man, I kill the eye, Ariel. I save both of us.

In the short story "The Tell Tale Heart", the narrator's confession about the murder that occurred was considered a form of crime committed by people who have psychiatric disorders. In addition, that confession could not prove that actually happened. However, in the film adaptation, killing was an act of self-defense and save others. The presence of Ariel's figure makes Sean's murder look like a form of liberation from a cruel and frightening figure for Sean.

The visualization of Ariel that base on Sean's imagination is a form of objectification of women. Sean created a woman who is intelligent, sensual, weak and always need his protection. This imagination is a cage for woman to live in man's ideal type. In other word, being pretty, weak, and understand what man want are the only things that woman can and have to do.This can be seen from Ariel's words; "I am so saved in you arms"(48:20 - 48:22). The utterance shows Sean wanted an acknowledgment that he did the right thing and protect 
other people. Ferguson said that women are often used as sexual objects in literary works. They become figures that men wanted and being someone that is used as sexual slave.

This sexual objectification demand woman to be sex object that always accessible and available to men [11]. Women is portrayed according to men's fantasy and treat them based on their appearance. [12] treat woman as sexual object means seperated women bode from her personality and make her an an object that fulfill man sexual desire. The female character in this film, Ariel, was a man's fantasy of ideal woman and become sexual object through her appearance, gestures and behaviour.

\section{Conclusion}

The strength of Edgar Allan Poe's works lies in the narration and symbols in the work. By using a little narration, Poe can describe the dark side of the human mind. The greatness of Poe's writings made his work adapted into various works. One of them is the film The Tell Tale Heart. However, in the process of ecranisation, this film adds several elements that can change the narrative and ideology of the text. The female character in this film shows some negative images of woman that usually showed in literary works. These images not only creates a different meaning of this works, but also trap women into a certain stereotypes, such as, demanding, dependent, and weak. These images strengthen the influence of partriarchy in a recent works. This film presents a more complicated narrative so that the interpretation of this film will also be very different. Therefore, this film can be analyzed from various aspects of research.

\section{Refferences}

[1] Poe, Edgar Allan. 1843. "The Tell Tale Heart"

[2] Hillerby, C., \& Poe, E. A. (2013). Mind-Style in Edgar Allan Poe's The Tell-Tale Heart. INNERVATE Leading Undergraduate Work in English, 6(2009), 86-95.

[3] Amir, Shamaila. (2017). Analysis of the Short Story " The Tell - Tale Heart” "by. II(Iii), 596-606.

[4] Rajan, G. (1988). A Feminist Rereading of Poe's "The Tell-Tale Heart." Papers on Language \& Literature.

[5] Sandoval Fierro, Daniela. (2014). "The Psychopath in Dostoyevsky and Poe: A Psychological insighof a killer." JACLR: Journal of Artistic Creation and Literary Research 2.1 (2014): 37-50 $<$ https://www.ucm.es/siim/journal-of-artistic-creation-and-literary-research>

[6] Damono, Sapardi Djoko. 2016. Alih Wahana. Editum

[7] Istadiyantha. 2017. (2017). INFIDELITY AGAINST THE VALUES OF LITERARY WRITING? 83-92. https://doi.org/10.24036/jh.v16i1.7961

[8] Ferguson, Mary Anne. 1977. Image of Woman in Literature. 2nd ed. USA: Mifflin Company.

[9] Vyomakesisri, T. (2017). Presentation of Women in Literature from Past to Present Tippabhotla Vyomakesisri. 22(11), 18-20. https://doi.org/10.9790/0837-2211091820

[10] Peterson, J. (1996). IGender Bias and Stereotyping in Young Adult Literature. Children's Book and Media Review, 17(3).

[11] Loughnan, S., \& Pacilli, M. G. (2014). Seeing (and treating) others as sexual objects: Toward a more complete mapping of sexual objectification. TPM - Testing, Psychometrics, Methodology in Applied Psychology, 21(3), 309-325. https://doi.org/10.4473/TPM21.3.6

[12] Szymanski, D. M., Moffitt, L. B., \& Carr, E. R. (2011). Sexual Objectification of Women: Advances to Theory and Research 147. The Counseling Psychologist, 39(1), 6-38. https://doi.org/10.1177/0011000010378402 
